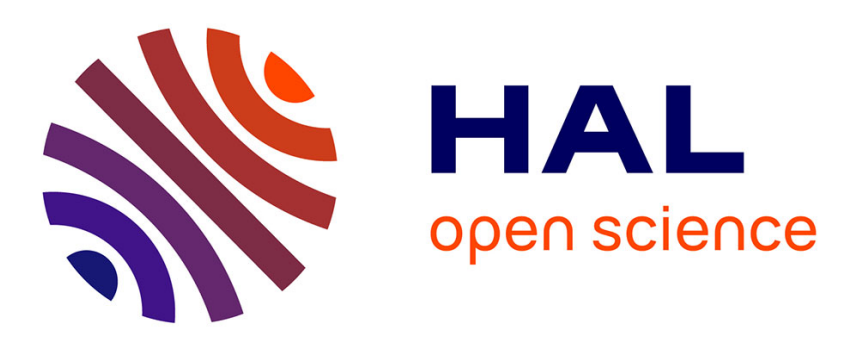

\title{
The c.859G $>\mathrm{C}$ variant in the SMN2 gene is associated with both type II and III SMA and originates from a common ancestor
}

\author{
Sara Bernal, Laura Alías, Maria Jesus Barceló, Eva Also-Rallo, Rebeca \\ Martínez-Hernández, Josep Gámez, Encarnación Guillén, Jordi Rosell, Inés \\ Hernando, Francisco J Rodríguez-Alvarez, et al.
}

\section{To cite this version:}

Sara Bernal, Laura Alías, Maria Jesus Barceló, Eva Also-Rallo, Rebeca Martínez-Hernández, et al.. The c. $859 \mathrm{G}>\mathrm{C}$ variant in the SMN2 gene is associated with both type II and III SMA and originates from a common ancestor. Journal of Medical Genetics, 2010, 47 (9), pp.640. 10.1136/jmg.2010.079004 . hal-00557399

\section{HAL Id: hal-00557399 https://hal.science/hal-00557399}

Submitted on 19 Jan 2011

HAL is a multi-disciplinary open access archive for the deposit and dissemination of scientific research documents, whether they are published or not. The documents may come from teaching and research institutions in France or abroad, or from public or private research centers.
L'archive ouverte pluridisciplinaire HAL, est destinée au dépôt et à la diffusion de documents scientifiques de niveau recherche, publiés ou non, émanant des établissements d'enseignement et de recherche français ou étrangers, des laboratoires publics ou privés. 


\section{The c.859G>C variant in the SMN2 gene is associated with both type II and III SMA and originates from a common ancestor}

Sara Bernal, ${ }^{1}$ Laura Alías, ${ }^{1}$ María Jesús Barceló, ${ }^{1}$ Eva Also-Rallo, ${ }^{1}$ Rebeca MartínezHernández, ${ }^{1}$ Josep Gámez, ${ }^{2}$ Encarnación Guillén, ${ }^{3}$ Jordi Rosell, ${ }^{4}$ Inés Hernando, ${ }^{5}$ Francisco J. Rodríguez-Alvarez, ${ }^{6}$ Salud Borrego, ${ }^{7}$ José M. Millán, ${ }^{8}$ Concepción Hernández-Chico, ${ }^{6}$ Montserrat Baiget, ${ }^{1}$ Pablo Fuentes-Prior, ${ }^{9}$ Eduardo F. Tizzano ${ }^{1 *}$.

1. Servei de Genètica, Hospital de la Santa Creu i Sant Pau, and CIBERER, Barcelona, Spain.

2. Servei de Neurología, Hospital Vall d'Hebron, Barcelona, Spain.

3. Genética Clínica, Hospital Virgen de la Arrixaca, Murcia, Spain.

4. Departamento de Genética, Hospital Son Dureta, Palma de Mallorca, Spain.

5. Servicio de Genética, Hospital Universitario de Asturias, Oviedo, Spain.

6. Unidad de Genética, Hospital Ramón y Cajal, and CIBERER, Madrid, Spain.

7. Unidad de Gestión Clínica de Genética, Reproducción y Medicina Fetal, Hospital Virgen del Rocío and CIBERER, Sevilla, Spain.

8. Unidad de Genética, Hospital La Fe, and CIBERER, Valencia, Spain.

9. Unitat Bases Moleculars de les Malalties, Research Institute, Hospital de la Santa Creu i Sant Pau, Barcelona, Spain.

${ }^{*}$ Correspondence to: Eduardo F. Tizzano, M.D., Ph.D. Genetics, Hospital de la Santa Creu i Sant Pau, Sant Antoni Ma. Claret 167, 08025 Barcelona, Spain; Fax: +34 93291 9494; Tel: +34 93291 9361; E-mail: etizzano@santpau.cat

Running title: Positive modifier effect of the SMN2 c.859G>C variant in SMA 
Homozygous mutations of the telomeric SMN1 gene lead to degeneration of motor neurons causing spinal muscular atrophy (SMA). ${ }^{1}$ A highly similar centromeric gene (SMN2) can only partially compensate for SMN1 deficiency. The c.859G>C variant in SMN2, has been recently reported as a positive disease modifier. ${ }^{2,3}$ We identified the variant in 10 unrelated chronic SMA patients with a wide spectrum of phenotypes ranging from type II patients who can only sit to adult walkers. Haplotye analysis strongly suggests that the variant originated from a common ancestor. Our results confirm that the $\mathrm{c} .859 \mathrm{G}>\mathrm{C}$ variant is a milder SMN2 allele and predict a direct correlation between SMN activity and phenotypic severity.

Based on age at onset and achieved milestones, SMA is classified into types I (the most severe form, characterised by generalised muscle weakness and hypotonia within the first six months of live); II, which manifests after the age of 6 months, affected children are able to sit but they never walk unaided; and III, in which patients eventually lose their ability to walk unassisted. Type III SMA is further divided into IIla, with clinical symptoms appearing before the age of 3 , and IIIb, with onset between 3 and 20 years. ${ }^{4}$

Although both SMN1 and SMN2 encode in principle identical proteins, a C-to-T transition within exon 7 of SMN2 leads to a high proportion of transcripts that lack this exon, resulting in an unstable, non-functional protein ${ }^{5}$. However, the expected inverse correlation between SMN2 copy number and severity of SMA disease (most type I, II and III SMA patients carry two, three, and three or four SMN2 copies, respectively) is not absolute, ${ }^{6,7}$ and some patients with two SMN2 copies show mild phenotypes, suggesting that other factors modulate disease progression.

We studied 261 unrelated Spanish SMA patients (Table 1), and six pairs of SMA discordant siblings with homozygous absence of the SMN1 gene, 10 parents of patients with the $\mathrm{c} .859 \mathrm{G}>\mathrm{C}$ variant, and 105 unrelated healthy individuals, five of whom lack the SMN2 gene. Informed consent was obtained from all subjects studied. Criteria to evaluate 
phenotype variability of the patients were age of onset, progression of motor milestones and age of loss of walking ability. We used LightCycler and multiplex ligation-dependent probe amplification (MLPA) for an accurate estimation of SMN gene copy number as described elsewhere. . $^{7}$

By direct sequencing using primers and methodology reported previously, ${ }^{9,10}$ we identified the SMN2 c.859G>C variant in 10 unrelated type II or III SMA patients (nine males, one female; patients' clinical and molecular data are summarised in Table 2). Five of these individuals had first clinical symptoms of the disease between 4 and 15 years of age, indicating type IIIb SMA; they all maintained walking capacity for several years. Three of these cases (patients 1-3) showed two SMN2 copies carrying the c.859G>C nucleotide change in homozygous state. The remaining two patients had three SMN2 copies and the variant in heterozygous state, with two copies of wild-type SMN2 and one that carries the c.859G >C variant. Patient 6 (type IIla) carries two SMN2 copies and the variant in heterozygous state. He started to walk at 18 months, but muscle weakness manifested around two years and was generalised at six years old. The other four individuals with 2 SMN2 copies and the variant in heterozygous state (patients 7-10) developed type II disease. Altogether, 8 out of 16 patients with the chronic forms but only two SMN2 copies were positive for the variant (Table 1). The analysis of ten parents confirmed that the variant has been transmitted either maternally and/or paternally (Table 2).

The variant was not detected in any of the non-discordant cases: 126 type I SMA patients with two SMN2 copies, 55 type II patients with three SMN2 copies, and eight walkers with four SMN2 copies. Furthermore, the variant was neither found in the six pairs of SMA discordant sibling or individuals without SMN2 genes but was present in 2 of 105 healthy individuals analysed.

Haplotype characterisation ${ }^{10}$ showed that the 10 patients with the variant presented a common allele of $193 \mathrm{bp}$ or $(\mathrm{CA})_{21}$ in the C272 multicopy marker, which is closest to the 5'-end 
of the SMN genes. Analysis of the C212 marker revealed two alleles of $227 \mathrm{bp}$ or $(\mathrm{CA})_{30}$ repeats $(n=7)$ and $225 \mathrm{bp}$ or $(C A)_{29}$ repeats $(n=3)$; this minimal size difference could be explained by replication slippage in a previous generation (Table 2 and Supplemental Figure 1). In striking contrast, these alleles were rarely associated with SMN2 in SMA patients without the variant. Thus, the linkage disequilibrium of the c.859G $>C$ variant with these alleles strongly suggests that it originated from a common ancestor.

Table 1. Distribution of the $\mathrm{c} .859 \mathrm{G}>\mathrm{C}$ variant among 261 SMA patients according to their phenotype and number of SMN2 copies. Note that the variant is positive in 8 of $16(50 \%)$ discordant type II and III cases with two SMN2 copies.

\begin{tabular}{|c|c|c|c|c|c|c|}
\hline SMA type & $I(n=126)$ & \multicolumn{2}{|c|}{ II (n=66) } & \multicolumn{3}{c|}{ III (n=69) } \\
\hline SMN2 copies & 2 & $2(n=11)$ & $3(n=55)$ & $\mathbf{2 ( n = 5 )}$ & $3(n=56)$ & $4(n=8)$ \\
\hline $\begin{array}{c}\text { Patients with the } \\
\text { C.859G>C variant }\end{array}$ & 0 & $4(36 \%)$ & 0 & $4(80 \%)$ & $2(3.6 \%)$ & 0 \\
\hline Total positive & 0 & \multicolumn{3}{|c|}{4} & \multicolumn{3}{|c|}{6} \\
\hline
\end{tabular}


Table 2. Clinical and molecular data of 10 Spanish SMA patients with homozygous absence of the SMN1 gene and with the C.859G>C variant in the SMN2 gene. NAIP + indicates at least one copy of the NAIP gene. Alleles associated with the $\mathrm{c} .859 \mathrm{G}>\mathrm{C}$ variant for $\mathrm{C} 272$ (Ag1-CA) and C212 markers are in bold. NA= parents were not available for study. *Used only to cover long distances. ${ }^{* *}$ This patient had an affected sister who died at the age of six due to pneumonia (further clinical data not available). ${ }^{* * *}$ Never walked. ${ }^{* * *}$ This patient is not yet using wheelchair because of her age although was never able to walk unaided.

\begin{tabular}{|c|c|c|c|c|c|c|c|c|c|c|}
\hline Patient & 1 & 2 & 3 & 4 & 5 & 6 & 7 & 8 & 9 & 10 \\
\hline Gender & Male & Male & Male & Male & Male & Male & Male & Male & Male & Female \\
\hline Age (years) & 65 & 36 & 22 & 59 & 34 & 18 & 30 & 12 & 5 & 3 \\
\hline SMA type & Illb & IIIb & IIlb & IIlb & IIlb & Illa & II & II & II & II \\
\hline $\begin{array}{l}\text { Age at onset of weakness } \\
\text { (mths / yrs) }\end{array}$ & 15 yrs & $14 \mathrm{yrs}$ & $4 \mathrm{yrs}$ & $14 \mathrm{yrs}$ & $13 \mathrm{yrs}$ & $<3$ yrs & 7 mths & $8-9$ mths & 12 mths & 14 mths \\
\hline Walked unaided & Yes & Yes & Yes & Yes & Yes & Yes & No & No & No & No \\
\hline Wheelchair bound (age) & $\begin{array}{c}\text { Yes } \\
\text { (59 yrs) } \\
\end{array}$ & No & No & Recently* & Recently* & $\begin{array}{c}\text { Yes } \\
(6 \mathrm{yrs})^{* *}\end{array}$ & Yes $^{* * *}$ & Yes $^{* * *}$ & Yes $^{* * *}$ & $-* * * *$ \\
\hline SMN2 copies & 2 & 2 & 2 & 3 & 3 & 2 & 2 & 2 & 2 & 2 \\
\hline c.859G $>C$ in SMN2 & Homoz. & Homoz. & Homoz. & Heteroz. & Heteroz. & Heteroz. & Heteroz. & Heteroz. & Heteroz. & Heteroz. \\
\hline Telomeric NAIP & + & - & - & + & - & - & - & - & - & - \\
\hline Parental inheritance & NA & Both & NA & NA & NA & Maternal & Paternal & NA & Paternal & Maternal \\
\hline C272 alleles & 193 & 193 & 193 & $\begin{array}{l}189 \\
191 \\
\mathbf{1 9 3} \\
\end{array}$ & $\begin{array}{l}181 \\
189 \\
193 \\
\end{array}$ & $\begin{array}{l}181 \\
193\end{array}$ & $\begin{array}{l}183 \\
193\end{array}$ & $\begin{array}{l}181 \\
193\end{array}$ & $\begin{array}{l}183 \\
193\end{array}$ & $\begin{array}{l}181 \\
193\end{array}$ \\
\hline C212 alleles & 225 & 227 & 227 & $\begin{array}{l}225 \\
227 \\
233\end{array}$ & $\begin{array}{l}219 \\
221 \\
225\end{array}$ & $\begin{array}{l}217 \\
227\end{array}$ & $\begin{array}{l}217 \\
225\end{array}$ & $\begin{array}{l}215 \\
227\end{array}$ & $\begin{array}{l}217 \\
227\end{array}$ & $\begin{array}{l}215 \\
227\end{array}$ \\
\hline
\end{tabular}


Two previous reports of the $\mathrm{c} .859 \mathrm{G}>\mathrm{C}$ variant described patients with type III SMA. ${ }^{2,3}$ However, in our series it was also found in four unrelated patients with type II disease (two SMN2 copies with the variant in heterozygous state; Table 2). Underscoring the impact of SMN dosage on disease phenotype, we detected the c.859G>C variant in heterozygous form in two type IIIb cases with three SMN2 copies, while a patient also carrying the variant in heterozygous state but only two SMN2 copies suffered from the more severe type IIla form. A homozygous type IIla patient who inherited two copies of the c.859G>C variant from his mother in the same chromosome in cis position has been previously reported. ${ }^{3}$ The parents of one of our patients homozygous for the SMN2 variant were consanguineous, and both transmitted the variant (patient 2). Thus, the phenotype spectrum associated with the SMN2 c.859G $>\mathrm{C}$ variant ranges from classical type II patients to adult type IIlb walkers depending on the homozygous or heterozygous state of the variant, the copy number of SMN2 genes, and whether variant SMN2 copies are present in cis or trans.

The c.859G $>C$ variant was not found in 126 patients with type I SMA and two SMN2 copies, similar to previous observations in 82 cases. $^{2,3}$ Altogether, over 200 patients with the most severe disease form from various origins have been studied, which strongly suggests that the variant should not be expected in these patients. Instead, the c.859G>C mutation appears to be restricted to discrepant cases of milder phenotype, and might be found in approximately half of the patients with only two SMN2 copies but chronic SMA. When stratifying these patients according to SMA type, the frequency reaches $80 \%$ in our type III cases (Table 1). Interestingly, all but two type IIIb patients who carry the c.859G>C variant lack NAIP, which contrasts with the low frequency of NAIP deletion reported in chronic SMA cases $(10-15 \%)$.

In conclusion, we confirm that the SMN2 c.859C>G variant is a milder SMA allele, which is present in a minority of patients with chronic SMA, but not in any with type I disease. 
Our results indicate that there is a direct correlation between SMN activity and disease severity.

Acknowledgements: We wish to thank the consenting parents and patients who made this study possible. We are indebted to all the colleagues and laboratories that referred samples for this study.

Funding: SB, RMH, FJMA and EA were funded by GENAME Project. LA and FJMA are also supported by CIBERER. The project was funded by grants FIS08-0479 to EFT.

Competing interests: None.

"The Corresponding Author has the right to grant on behalf of all authors and does grant on behalf of all authors, an exclusive licence (or non exclusive for government employees) on a worldwide basis to the BMJ Publishing Group Ltd to permit this article (if accepted) to be published in Journal of Medical Genetics and any other BMJPGL products and sublicences such use and exploit all subsidiary rights, as set out in our licence (http://group.bmj.com/products/journals/instructions-for-authors/licence-forms)." 


\section{Supplemental Figure Legend}

Figure 1. Electropherogram of the 10 patients with the $c .859 \mathrm{G}>\mathrm{C}$ variant in the SMN2 genes.

(A) Results of the C272 marker showing the common 193 peak corresponding to $(C A)_{21}$ repeats. Note that the homozygous patients for the variant showed only one peak;

(B) Results of the C212 marker showing two common peaks of 225 (CA) 29 repeats and 227 $(C A)_{30}$ repeats. Thus, the common haplotypes associated with the SMN2 variant are 193-225 or 193-227. In contrast, the 193-bp allele was detected in only 7 of 120 SMN2 genes in 50 SMA patients without the c.859G>C variant (6\%), while the 225- and 227-bp alleles of C212 were identified in 17 and 5 SMN2 genes (14 and 4\%, respectively). None of these samples showed haplotypes $193-225$ or 193-227. M=ROX molecular weight marker 


\section{REFERENCES}

1 Lefebvre S, Burglen L, Reboullet S, Clermont O, Burlet P, Viollet L, Benichou B, Cruaud C, Millasseau P, Zeviani M, et al. Identification and characterization of a spinal muscular atrophy-determining gene. Cell 1995;80:155-65.

2 Prior TW, Krainer AR, Hua Y, Swoboda KJ, Snyder PC, Bridgeman SJ, Burghes AHM, Kissel JT. A positive modifier of spinal muscular atrophy in the SMN2 gene. Am J Hum Genet 2009;85:408-13.

3 Vezain M, Saugier-Veber P, Goina E, Touraine R, Manel V, Toutain A, Fehrenbach S, Frébourg $\mathrm{T}$, Pagani $\mathrm{F}$, Tosi $\mathrm{M}$, Martins A. A rare SMN2 variant in a previously unrecognized composite splicing regulatory element induces exon 7 inclusion and reduces the clinical severity of spinal muscular atrophy. Hum Mutat 2010;31:E1110E25.

4 Zerres K, Wirth B, Rudnik-Schöneborn S. Spinal muscular atrophy-clinical and genetic correlations. Neuromuscul Disord 1997;7:202-7.

5 Lorson CL, Hahnen E, Androphy EJ, Wirth B. A single nucleotide in the SMN gene regulates splicing and is responsible for spinal muscular atrophy. Proc Natl Acad Sci USA 1999;96:6307-11.

6 Feldkötter M, Schwarzer V, Wirth R, Wienker TF, Wirth B. Quantitative analyses of SMN1 and SMN2 based on real-time LightCycler PCR: Fast and highly reliable carrier testing and prediction of severity of spinal muscular atrophy. Am J Hum Genet 2002;70:358-68.

7 Cuscó I, Barceló MJ, Rojas-García R, Illa I, Gamez J, Cervera C, Pou A, Izquierdo G, Baiget M, Tizzano EF. SMN2 copy number predicts acute or chronic spinal muscular atrophy but does not account for intrafamilial variability in siblings. $J$ Neurol 2006;253:21-5. 
8 Huang $\mathrm{C}-\mathrm{H}$, Chang $\mathrm{Y}-\mathrm{Y}$, Chen C-H, Kuo Y-S, Hwu W-L, Gerdes T, Ko T-M. Copy number analysis of survival motor neuron genes by multiplex ligation-dependent probe amplification. Genet Med 2007;9:241-8.

9 Cuscó I, Barceló MJ, del Rio E, Baiget M, Tizzano EF. Detection of novel mutations in the SMN Tudor domain in type I SMA patients. Neurology 2004;63:146-9.

10 Alías L, Bernal S, Fuentes-Prior P, Barcelo MJ, Also E, Martinez-Hernandez R, Rodriguez-Alvarez FJ, Martin Y, Aller E, Grau E, Pecina A, Antinolo G, Galan E, Rosa AL, Fernandez-Burriel M, Borrego S, Millan JM, Hernandez-Chico C, Baiget M, Tizzano EF. Mutation update of spinal muscular atrophy in Spain: molecular characterization of 745 unrelated patients and identification of four novel mutations in the SMN1 gene. Hum Genet 2009;125:29-39.

\section{LICENCE FOR PUBLICATION STATEMENT}

"I Eduardo F. Tizzano, the Corresponding Author of this article (the Contribution") has the right to grant on behalf of all authors and does grant on behalf of all authors, a licence to the BMJ Publishing Group Ltd and its licensees, to permit this Contribution (if accepted) to be published in Journal of Medical Genetics (JMG) and any other BMJ Group products and to exploit all subsidiary rights, as set out in our licence set out at:

(http://group.bmj.com/products/journals/instructions-for-authors/licence-forms)

Please tick one or more boxes as appropriate:

_ I am the sole author of the Contribution.

\section{I am one author signing on behalf of all co-owners of the Contribution.}

_ The Contribution has been made in the course of my employment and I am signing as authorised by my employer.

_ I am a US Federal Government employee acting in the course of my employment.

_ I am not a US Federal Government employee, but some or all of my co-authors are.

_ I am an employee of the UK Government acting in the course of my employment

_ I am not an employee of the UK Government acting in the course of my employment but some/all of my co-authors are. 